\title{
Development of Primary/Secondary Schools in Colonial Times and the Need for Sustainable Innovations, Growth and Value Creation: A Comparative Analysis
}

\author{
Dr. Celestina Imade Harry* \\ Department of Educational Foundations, Faculty of Education, University of Port Harcourt, Choba
}

*Corresponding Author:Dr. Celestina Imade Harry,Department of Educational Foundations, Faculty of Education, University of Port Harcourt, Choba

\begin{abstract}
Innovation in Africa is now taking off in many African countries especially in Kenya, Nigeria, Tanzania and Ghana. Innovation is seen as a viable solution to economic and social challenges in Africa and effective policy is needed to promote it. This paper looks back to colonial times when the schools were established in different colonies. After three decades of trial and error, innovative policy is now taking off in Africa - strategy for Africa 2024 (STISA - 2024). This paper therefore looked into innovations and strategies in education for sustainable development in Africa.
\end{abstract}

Keywords:Planning, Implementation and Innovative Policy.

\section{INTRODUCTION}

The process of educational development in Africa, especially the pre-independence era has seen a lot of contradictions in colonial policies. These colonial policies were suppose to raise the hopes, aspirations and expectations of all Africans. These inadequacies and contradictions of colonial policies are apparent from the British experiments in Nigeria, Kenya, Ghana and Tanzania. The contradictions between colonial policies and real African hopes, aspirations and expectations were also apparent from the crises that followed the initial efforts of African leaders at educational policy formulation and implementation. All these crises were easily seen from the experiences of Ghana, Kenya, Nigeria and Tanzania.

\section{Nigeria}

In 1940s, Nigeria had the most difficult periods in her educational history.For example, in pursuance to the need for a revision of the educational system, a new education ordinance (No. 9 of 1942) was passed in March 1942. This ordinance which contemplated a total grant of the salaries of certificated teachers without reference to the efficiency of the school was rejected by the Advisory Committee.Following the failure of the ordinance, a new ten year plan for educational development was evolved and this effort gave rise to the 1947 "Memorandum on Education Policy in Nigeria" and the Educational Ordinance of 1948. These two documents established regulations for grants-in-aid, redefined the relationship between the government and voluntary agencies, advanced the policy of involving local communities in the control of education and of entrusting local Education Authorities with the responsibility and administration of primary education in their areas. They also prepared Nigerians for the next stage in which regionalisation became a feature of the educational system (Lewis, 1962).

The 1950s witnessed a phenomena expansion in education. It was also a very critical political era in Nigeria's pre-independence history. However, between the period of 1951 and 1960, there was a new constitution every three years, whereas, only two constitutions were introduced between 1861 and 1950 (these were the 1923 and the 1946 constitutions). During the period of the Macpherson constitution in 1951, this constitution which sowed the seed of discord that has kept Nigeria permanently gropping for unity and self-definition, provided for election to the regional houses of assembly, empowered each region to raise and appropriate funds and, more importantly to pass laws on education. With the regionalisation of education in 1951 and the rise to power of the three major 
tribal-based political parties in the three regions in 1952, intensive rivalry developed and each region tried to out shine the other in the provision of social amenities to its people. In the Western and Eastern regions, the highest priority was placed on education (Lewis, 1965).

With the introduction of the UPE programme in 1976, enrolments soared in all schools in Nigeria with the result that the primary school population, which stood at 2,912,000 in 1960 (representing 37 percent of school age children) rose to $12,415,688$ (representing 95 percent of school age children) in the $1979 / 1980$ school year.

\section{Ghana}

In Ghana, the educational policy articulated by the then governor Guggisberg was given a legal form when the legislative council passed the 1925 education ordinance, which remained in force until 1950. The educational policy was attributed to the great expansion in teacher training and primary enrolments in the 1940s (McWilliam and Kwamena-Poh, 1975).

When the victory of the Convention People Party (CPP) was announced after the Ghana's first general election in February 1951, Dr. Nkrumah declared that his government's aim in education was to meet, as soon as possible, the most urgent and popular need of his people which was for "a measure of education for every child of school - going age". The determination of the government to accelerate the implementation of this lofty objective, led to the abolition of tuition fees in all primary schools in Ghana.

After the decision to make primary education free, enrolments increased and by 1957 when Ghana gained her political independence, there were over 450,000 pupils (as against 204,000 pupils in 1950). It is important to note that the rapid expansion implied here was made possible through shared responsibility between the central government and local authorities which by 1954 were paying $40 \%$ of the primary school teachers' salaries (Lewis, 1962).

In 1961, an Education Act stated inter alia, that "No fee, other than the payment for the provision of essential books, stationaries or materials required by pupils for use in practical work, shall be charged in respect of tuition at a public primary, middle or special school".

The 'Act' also stipulated that it was illegal for the head of any school or college to ask questions about religious affiliation and hence, to be influenced by such consideration in granting or refusing admissions (Government of Ghana, 1967).

The immediate effects of the introduction of free and compulsory primary education, were more dramatic than had been expected. For instance, a total of 2,493 new primary schools were opened in September 1961 and 219,480 additional children were enrolled in the first year of their classes. By the $1979 / 80$ school year, about 1,799,430 pupils were attending 10,661 public primary schools. In addition, the number of teacher training colleges grew from 31 in 1961 (with a student population of 5,452 ) to 203 , with a student population of nearly 85,000 by the end of $1970 / 80$ school year (Ukeje, 1989).

\section{Kenya}

In 1949, the Beecher's Report published in September 1949, like Guggisberg 1929 Education Ordinance in Ghana, served as the framework for educational planning during the pre-independence years. This report was able to identified the most serious problem of Kenya's primary school as "population explosion at all levels without adequate financial provision and control." In addition, teacher training supervision and other aspects of planned development failed to keep pace with primary school expansion and as a result, quality was sacrificed at the expense of quantity.

In order to reverse this trend, the report recommended strict financial control and strict supervision to control primary school expansion. Secondly, it recommended the restructuring of Kenya's educational system by introducing the 4-4-4 system of primary intermediate and secondary school to replace the previous 6-2-4 organisation. Thirdly, it recommended the redesignation of independent schools to voluntary agency schools thus qualifying them for grants-in-aid (Government of Kenya 1964).

Again, the sessional paper of 1956/57 defined the purpose of the development programme planned for 1957-1960 as that of trying "to maintain European standards, to raise Asian standards and to create 
African standards." (This clearly shows that a situation of racial imbalance existed in Kenya's educational system before independence. Unfortunately this proposition was not translated into action since the allocation of funds revealed that the European community with $1 \%$ of the primary school population, was to receive $19 \%$ of the total budget for education, the Asian community which had 3\% of the population was to receive $28 \%$ of the budget while to Africans who constituted $96 \%$ of the school population, was allocated $53 \%$ of the budget. To compound this problem the number of African schools by 1960 was more than double the forecast contained in the Beecher's Report on which all projections, plans were based (Shesfield, 1973).

The Ominde Commission Report of 1964 established new milestones in the nation's schools both as a vital instrument of economic development and as a central agent of social change. Secondly it emphasized that education in the future would reflect national rather than sectarian interests. Between 1964 and 1979/1980, a remarkable expansion at all levels took place in Kenya's schools. This situation placed a particularly heavy burden on the nation's resources between the period of 19661975, for instance, educational expenditures increased by $40 \%$ and, by $1979 / 1980$, Kenya's educational expenditures amounted to $7 \%$ of her gross domestic product and $75 \%$ of the total expenditure went into primary education. Kenya was, however, particularly at an advantage in the sense that quite a large amount of her educational expenditures came from overseas (Stabber, 1969; Government of Kenya, 1964).

For Nigeria however, with the introduction of the UPE programme in 1975, enrolment soared in all schools in Nigeria with the result that the primary school population, which stood at a total of 2,912,000 in 1960 (representing 37\% of school-age had risen to 12,415,688 (representing 95 percent of school-age children) in the 1979/80 school year.

\section{Tanzania}

In 1947, the colonial administration put into effect a ten year plan for African education. The objectives of the plan were to triple the number of pupils attending the first four years of the primary school courses and to develop district day and boarding schools to give an additional two years of presecondary education to about $25 \%$ of standard IV leavers.

However, in December 1958, a committee on integration of education was appointed. Confronted with separate systems that had existed along separate racial lines with differing modes of financing, the task of the committee was therefore a very difficult one. Nevertheless, political necessity compelled it to produce a far-reaching recommendations in its report published in October 1959. Among the committee's vital recommendations were the abolition of the non-native education tax and the replacement, with a single Advisory Council on Education, of the various education authorities and advisory committees on education. Also, the report suggested as a first step towards integration, the adoption of a uniform eight-year curriculum except for the language of education (Castle, 1966, Scanlon, 1966).

The Committee's Report gave rise to an education ordinance passed in 1961 which authorised a number of departures from, colonial institutional arrangements. First, the semi-autonomous, non African Education Authorities were abolished and the Department of Education which had been organised to cater for separate racial groups were upgraded in status to a ministry and reorganised along functional lines. Secondly the Advisory Committee on Native Education was replaced by an Advisory Council on Education set up to proffer advises on the education of all children irrespective of race etc. However, very shortly before independence, arrangements were also made to develop an agency outside the ministry called the Teacher's Training Advisory Board which had responsibilities for advising the Minister of Education on Syllabuses training courses and other professional mall.

When Dr. Nyerere released a major policy statement on March 9, 1967, it was entitled Education for Self-Reliance. This thesis dealt with the need for radically redesigning the organization and content of education in Tanzania to foster self-reliance, cooperativeness, and a sense of equality. The major objective of education for self-reliance was the use of education to create a new and appropriate kind of society in Tanzania. The concept of this new society, with its roots in the traditional past, was first clearly articulated in Ujamaa 1962. Among the many themes of education for self-reliance, Dr. Nyerere was particularly critical of the fatal disabilities of colonial education which included. 
Development of Primary/Secondary Schools in Colonial Times and the Need for Sustainable Innovations, Growth and Value Creation: A Comparative Analysis

Such shortcomings as the fact that British models of school organisation and curriculum were uncritically imported into Africa without regard for the change of setting and the differences in national needs, and the fact that colonial education primarily tried to reinforce a social ethic compounded of subservience and economic individualism etc. (Svendsen and Yeisen, 1969).

Thus the major objective of education for self-reliance was to deal with the most glaring of these deficiencies. First, it abolished the religiously based parallel - schooling system. Secondly, it injected more African content into the formerly, European oriented history courses and rapidly expanded public education facilities. Thirdly it de-emphasised the colonial legacy which was premised on the belief that primary education was solely justified as a preparation for the secondary school and that the process of becoming educated consisted almost exclusively of reading books to pass examinations. Consequently, in the new dispensation, certificates were no longer, considered as the only appropriate measure for attaining positions of responsibility.

Tordoff, (1967), again, every effort was made to correct the colonial impression that the school was "a place children went to and which they and their parents hoped would make it unnecessary for them to become farmers and therefore continue to live in the villages". In education for self-reliance, therefore the primary purpose of education was to foster the social goals of living together and working together for the common good. Our education must therefore inculcate a sense of commitment to the total community and help the pupils to accept the values appropriate to our own kind of future and those appropriate to our colonial past." Put more simply, the primary schools must not be separated from the community and their rural environment, instead "the pupils must remain an integral part of the family or community economic unit. The children must be made a part of the community by having responsibilities to the community and by having the community involved in school activities."

However, with the new dispensation, the role of the teacher was particularly important. He was expected to be "an adequate reflection of the general values of his community, exemplary in behaviour and standards of conduct, a good public servant who was interested in understanding and was helpful and loving towards his pupils (Resnick and Resnick, 1970). By the close of 1979/1980 school year, about 8000 schools absorbed $20 \%$ of the national budget to enable some 30,000 teachers to teach about $2,500,000$ pupils.

\section{A Focus on Educational DeVElopment in AFrica}

The Addis-Ababa Conference of 1961 was a "conference of African states on the development of education in Africa." This conference addressed itself to the problem of planning education in relation to economic and social development. The conference drew up two types of plans, a short term plan covering the period 1960-1965, and a twenty-year long term plan covering 1960-1980. Short-term plan, focussed on three main issues:

1. The expansion of secondary school education to raise secondary school enrolment which in 1961 constituted only three percent of the secondary school age population in middle Africa.

2. A change in the school curriculum to conform to development needs. Expansion of teacher training facilities especially for primary and secondary schools.

3. The objective of the short-term plan was to plan the educational system to meet man power needs. The objective of the long-term plan was to raise enrolment ratios of elementary schools, secondary schools and universities which stood at 40:3.0:0.2 in 1961 to 100:23.2.1 by 1980 as indicated in the projected figures in the table below as copied from (Harry, 2017).

Long Term Plan (1961-1980) Enrolment and Equivalent Percentages

\begin{tabular}{|l|l|l|l|l|}
\hline Educational Level & $\mathbf{1 9 6 1 - 1 9 6 2}$ & $\mathbf{1 9 6 5 - 1 9 6 6}$ & $\mathbf{1 9 7 0 - 1 9 7 1}$ & $\mathbf{1 9 8 0 - 1 9 8 1}$ \\
\hline & Enrolments (in thousands) & \multicolumn{2}{l|}{} \\
\hline Primary & $11,586.0$ & $15,279.0$ & $20,378.0$ & $32,808.0$ \\
\hline Secondary level & 903.7 & $1,833.5$ & $3,390.0$ & $5,905.4$ \\
\hline Higher & 25.5 & 30.3 & 55.0 & 328.0 \\
\hline & Percentage of age group enrolled & 71 & 100 \\
\hline Primary & 40 & 51 & 15 & 23 \\
\hline Secondary level & 3 & 9 & 0.4 & 2 \\
\hline Higher & 0.2 & 0.2 & \\
\hline
\end{tabular}


Development of Primary/Secondary Schools in Colonial Times and the Need for Sustainable Innovations, Growth and Value Creation: A Comparative Analysis

Source: Final Report: Conference of African States on the Development of Education in Africa, UNESCO, 1961 (Harry, 2017).

The inventory of educational needs that were established by the conference included the need for adult education, the need for stepping up the education of girls who constituted only $30 \%$ of primary school enrolment and $22 \%$ of secondary school enrolment. The need for the development of higher education geared to the production of high level - manpower, the need for teachers at all levels of the educational system, to be trained and be re-trained and the need for curriculum reform. On the basis of these needs the educational structure that was envisaged to have been attained by 1980 called for a six year free and compulsory primary education in order that $100 \%$ enrolment would be achieved by 1980.

\section{Development of Post-Primary Education in Ghana, Nigeria ANd KenYa}

For much of the developing countries of Africa, the transcendent event of the two decades (19501970) was the achievement of political independence. This was followed by the slow process of nation-building arising first, largely as a result of the lack of consistency between educational policies and systems and the development objectives, they were assumed to serve. Secondly, to the fact that the process of nation building sought, in many cases, to recast the diversity of ethnic, religious and cultural traditions into a new national formulation. Since political independence is more easily achieved than economic or cultural reconstruction, the practices and institutions chosen to replace the existing diversities were frequently those previously established by the colonial powers (Najman, 1972).

Moreover, between 1950-1970, education was considered, in most nations of Africa, to be a major instrument for the political, social, cultural leaders in Africa were convinced that a well supported and easily accessible educational system was an efficient means of making people politically and socially. Conscious and therefore, active participants in nation building and cultural processes. The education sector was therefore enthusiastically, but often simplistically, supported as the major supplier of skills for the economy. The more optimistic even expected that education would, on its own, stimulate the creation of jobs and thus generate economic development. Unfortunately, in spite of all good intentions and expectations, the education systems of most African nations did not offer a good base for national development either quantatively or qualitatively. Since they were ill-conceived and were not adapted to meaningful developmental needs (World Bank, 1974).

This situation underscores the importance of a comparative examination of educational experiences cross-nationally in order to ensure that future reforms and expansions of educational systems are done in such a way that they may contribute more meaningfully to national developmental needs and expectations by taking into consideration what efforts other nations must have made and what results that may have been achieved.

\section{Secondary Education 1950-1960}

Generally, in spite obvious internal measures which included local conferences, educational review commissions, various local development plans and programmes, a number of international conferences set the pace. For educational development in Africa during this period. For example, the Cambridge conference held in September 1952 under the joint auspices of the Nuffield foundation and the colonial office, tried to place on record the best views that could be formalized and expressed for the use of those responsible for planning and implementing educational developments. The report of this conference recommended, among other things, that the central government should take the responsibility for secondary and higher education. Secondary, that to determine the most appropriate organisational pattern for the African school system, three areas should be given balanced consideration in every territory during the planning stages, namely, what was educationally desirable what the people of the country desired and what was financially possible (Nuffield Foundation and Colonial Office, 1953).

In accordance with some resolutions of the United Nations General Assembly and the Economic Commission for Africa (ECA), the Minister of Education of African Nations met in Paris in March 1962 to discuss the implementation of the recommendations of the Addis Ababa Conference. This meeting also reaffirmed the high priority given to teacher training and the entire range of secondary 
education (UNECA, 1962). Another meeting on the implementation of the Addis-Ababa plan was held in Kinshasa in February and March 1963 under the auspices of the ECA. The Kinshasa meeting reaffirmed the resolutions of the Paris Conference but called for more aid from UNESCO and other sources to help African nations meet the budget deficits resulting from increasing educational expenditures. The outcomes of these conferences permeated every facet of educational planning and educational decision making in most African nations particularly between 1950-1970. For instance, in 1951, Ghana put into effect the Accelerated Development Plan for Education, which among other things, prevented bodies and private persons from opening New Secondary Schools unless such bodies or persons obtained prior approval from the Central Government and in addition, would be prepared to finance such schools (Government of Gold Coast, 1951).

In the Accelerated Development Plan, it was estimated that by 1957 there would be nearly 8,000 students in Ghana secondary schools. The actual enrolment in the 38 secondary schools receiving government assistance by 1957 was 9860 students. The spread of secondary education under the plan was tremendous and a notable achievement of this spread was the development of sixth - form work which started in 1949 and by 1956 was offered in over twenty secondary schools.

In Kenya the experience was slightly different. In fact, during the 1950's educational policy received very little attention in Kenya for the very reason that in contrast to the colonial government's enthusiasm, Africans were highly critical of the Beecher's Report which was to determine the pace of educational development during this period.

The Beecher Report had criticized the lack of control in Kenya's educational system as a result of which supervision, secondary education, teacher training and other aspects of planned development, failed to keep pace with expansion at the primary level.

In Beecher's words, the system was a 'tightly closed vicious circle in which everything expands except control (Wards, 1953). In order to reverse, this trend, Beecher recommended strict supervision to control primary school expansion while expansion at the secondary and teacher training levels was to continue to restore some semblance of balance to the system.

Two major reasons why Africans objected to Beecher's Report.

1. There was the complaint that Beecher's emphasis on quality rather than quantity meant that enrolment would grow too slowly thus frustrating African hopes for universal literacy.

2. The replacement of the 6-2-4 system with the 4-4-4 system. Many Africans argued that the fouryear primary school course would be too short to achieve permanent literacy, and that too few pupils would get beyond the fourth grade to make the intermediate level worthwhile.

Despite these criticisms, the Beecher Report remained a very important educational document in Kenya before independence.

Like the Beecher Report in Kenya and the Accelerated Development Plan for Education in Ghana, the Macpherson Constitution of 1951 made a big impact on education in Nigeria. Among other things, it provided that each region should have a legislature with power to enact legislation on education. The Education Act No. 17 of 1952 (Taiwo, 1980), enacted in the spirit of the new constitution, reflected the concern for raising the standard of work in schools particularly at the secondary school level, through the control of expansion and the provision for inspection. Probably influenced by Ghana's Accelerated Development Plan, the act stated that "No new school other than a government school could be opened without the consent in writing of the appropriate Regional Director."

When there was a revision of the 1951 constitution which gave birth to the Lyttelton Constitution of 1954. By this new constitution, Nigeria became a federation of three regions each with its own exclusive powers. The new constitution also made provision for three legislative lists namely, the executive list, the concurrent list and the residual list. The executive list was reserved for the central government and the residual list for the Regional Governments. The central and the Regional Governments could legislate on subjects which were on the concurrent list provided the federal law prevailed in the event of a conflict. Education, other than higher education, was residual subject. The effect of these changes was that the Nigerian educational system became a federal system consisting of three regional systems of education. The regions reacted to the new responsibility by enacting their 
respective education laws which became the basis of the regional activities on education. The Western region took the lead and enacted the Education Law No. 6 of 1955. The Eastern Region followed with its Education Law No. 28 of 1956, and the Northern Region with its Education Law No. 17 of 1956. The Federal Government enacted the Education (Lagos) Act No. 26 of 1957 covering the Federal Territory of Lagos. These laws and the Act had serious implications for the development of secondary education. At the down of independence in 1960, some 135,434 students were enrolled in secondary schools in Nigeria. However, the growing demand of a secondary school led to the appointment of the Ominde Commission in 1964. As Anderson 1969 and Sheffield (1973) pointed out, with the Ominde Report, Kenya broke new grounds in it's educational history because the report, apparently influenced by the Asby Report in Nigeria and the Addis-Ababa Conference report, evidenced a belief in the secondary school both as a vital instrument of economic development and as a central agent of social change.

\section{INNOVATION IN EDUCATION FOR SUSTAINABLE DEVELOPMENT IN AFRICA}

Innovation policy is now taking off in many African countries, innovation is seen as a viable option to economic and social challenges in Africa and effective policy is needed to promote it. To address this issue and need, the African Union has released the science, technology and innovation strategy for Africa - 2024 (STISA - 2024). This is to provide a framework for innovation strategies in member states and to encourage the coming together and enhance discussion. UNC - MERIT together with two specialised organisations under the African Union Commission (AUC) - the African Observatory for Science, Technology and Innovation (AOSTI) and the Pan African University Institute for Basic Science Technology and Innovation (PAU-ISTI) - organised a training course in Nairobi Kenya $6^{\text {th }}-$ $10^{\text {th }}$ October, 2014. The course on the Design and Evaluation of Innovation Policies for Africa (DEIPAfrica) was attended by representatives from the AUC, 11 countries from Southern and Eastern Africa, the New Partnership for Africa's Development (NEPAD), as well as two regional institutions: the Southern African Development Community (SADC).

In the past three decades, there have been many attempts to boost ST\&I activities in support of the socio-economic transformation of Africa. The 1980 Lagos Plan of Action for Economic Development could be cited as one of the frameworks. The target for African countries to spend at least $1 \%$ of their GDP on R\&D Sterms from the same Lagos Plan of Action. Subsequent decisions underscored the importance of investing in S\&T: among others, the 1987 Kilimanjaro Declaration, the 1988 Khartoum Declaration and the 1989 Abuja statement. The attention paid to S\&T put more emphasis on higher education and R\&D by easing research networks although recently less emphasis was put on innovation.

\section{Innovation Growth and Value Creation}

In addition to the role of providing public goods, science, technology and innovation (STI) serves as a crucial driver of rising prosperity and improved national competiveness. However, due to the fact that technological knowledge and skills are cumulative, first mover advantages have created a very uneven global landscape connecting local technological needs to international technological opportunities is a particular challenge for developing countries in Africa.

A well functioning STI ecosystem needs to include inter alia, political stability and well functioning institutions, an educated workforce; sound research and education infrastructure and linkages between public and private innovation actors enterprises committed to research and development; as well as balanced intellectual property rights. Given that knowledge exhibits several properties of a public good, there is a persistent danger of underinvestment, and policymakers have increasingly sought to improve the incentives to create and transfer knowledge from publicly funded research to enterprises, thereby reinforcing the impact of that research on innovation capacity. But addition to national strategies, regional and international frameworks including the United Nations and its agencies, funds, and programmes must respond in new ways to ensure that innovation is integrated into national development priorities, especially in developing countries. Here there is a need for collaboration and competition involving market incentives but also private and public partnerships across borders bridging the technological divide by promoting inclusive innovation. 
Governments will find it difficult to raise living standards in a sustained manner, feed their citizens, protect their environment, if they cannot find better, cheaper and smarter ways of producing goods and bringing them to market. The future therefore holds other challenges, where new technologies will be the key especially in the case of climate change is involved in both traditional and frontier markets, competition between innovators will be critical to ensure the development of socially useful products and processes at affordable prices.

The concept of sustainable development sustainable development includes strategies, like basic needs approach, employment, creation and income distribution, sustainable development and human development.

Sustainable development was propounded as an alternative development strategy for improving the living conditions of the human population without degrading the quality of the environment. The concept came into being following the realization that economic development and environment are closely linked. The findings of the World Commission on Environment and Development (WCED) entitled our Common Future (1987) and known as the Brundland Report actually popularized the concept. Sustainable development's aim is to build a more prosperous, just and secure future and to sustain and expand the environmental resource base. SD may be described as a process of change in which the exploitation of resources, the direction of investments, the orientation of technological development, and institutional change are made consistent with future as well as present needs.

However, there is an urgent need to adopt a risk - aversion strategy in the exploitation of natural resources for the following reasons.

- The multi-functionality of natural resources, for instances, the relationship between afforestation programme and the availability of land for other purposes.

- The existing imperfect understanding of the life support functions of natural environments.

- The lack of capability to provide substitutes for the life support functions.

- Any natural resources that are lost are often than not irreversible.

\section{Sustainable DeVelopment Challenges in AfRica}

In spite of the fact that most African countries gained political independence about forty years ago, most of them, especially in sub-Saharan Africa (SSA) are facing serious environmental, social, economic, political and educational crises. However, according to Harry (2017) these are some of the major problems that contribute to hinder economic development in Africa. They are:

1. Inadequate education and lack of information flow.

2. The huge external debt burden.

3. Ineffective policies for addressing the African economic crises.

4. High costs of dealing with transnational corporations

5. Negative impacts of natural and man-made disasters

6. Lack of good leadership

7. Inappropriate land tenure system

8. Lack of broad based development for all

9. Impacts of demographic changes and population pressures

10. Resource outflow from Africa

11. Declining commodity prices and unfair international market and trade practices

12. Declining agricultural production

13. Inappropriate production techniques in agriculture, industry, livestock and mining.

The environmental degradation problems of Africa have been analysed by writers and scholars from different perspectives. For some colonialism is the main case while others blame bad leadership. The high population growth rate is also regarded as a major cause of environmental problems in the continent because of the pressure it puts on its limited structures, resources and services. 
Environmental problems in Africa are caused by an interplay of a mixture of factors. However, blaming the international community alone can only facilitate initiatives taken by African countries to solve their own problems and in terms of their needs and resources.

\section{The Evolution of Sustainable Development in Africa}

According to Kaniaru (1998), the problem should be traced from the pre-independence era to the colonial and the post independence periods of educational development.

\section{The Pre-Colonial Period}

During the pre-colonial era, African societies had well-founded institutional arrangements for the management of common resources on behalf of the community. Institutions were organised in the form of kingdoms, chiefdoms and customs provided both men and women access to living and nonliving resources. Cultural taboos, norms, beliefs and ethics guided resources management considerations that were in harmony with the environment checks and balances were put in place to guard against any over-exploitation of natural resources and to maintain a good resource balance.

\section{Colonial Administration and the Emergence of Nation States}

The institution of colonialism and the emergence of nation-state put African institutions, customs, and taboos in a crises. Traditional resource management systems were replaced by commercial interests. The resource users were separated from the decision-makers. Institutions that fitted the traditional communities and their needs were destroyed during the colonial dispensation.

\section{The Post-Independence Period}

During the post independence African governments did not succeed in changing the status quo left by the colonial masters. Colonial institutions, as well as other legal and institutional arrangements in most African countries.

There were other problems like high population pressure and land degradation. Even deforestation and desertification.

\section{REFERENCES}

[1] Anderson, J. (1965). The Kenya Education Commission Report. An African View of Education Planning CER, ix, 201-207.

[2] Ashby Report (1960). Investment in Education. Lagos Federal Ministry of Education.

[3] Boon, E.K. (2017). An Overview of Sustainable Development in Africa. World Resources Institute and United Nations Environment Programme UNESCO ECLSS. Sample Chapters.

[4] Eastern Nigeria (1962). Report of the Commission on the Education System in eastern Nigeria. Enugu Government Printer.

[5] Fafuwa (1974). History of Education in Nigeria. London Geroge Allen and Urwin.

[6] Ghana Government (1971). Educational Statistics, 1968-1969, Accra Ministry of Education.

[7] Habison, F.W. (1963). "Education for Development". Scientific.

[8] Harry, C.I. (2011). The Prospects and Challenges of Universal Education: Historical Antecedents. In Okoh J.D., Oku O.O., Dienye V.U. (Eds) Basic Education in Nigeria Fundamental Exposition, Imo State Corporate Impressions Publishers.

[9] Harry, C.I. (2017). Comparative Education and Issues on National Systems. Port Harcourt: Pearl.

[10] Harry, C.I. (2017). Historical Relevance of Primary Education Reform Policy in Promoting Efficiency Security and National Development. Elixir International Journal of Education Technology, 11(2) (4823048234).

[11] Kenya Government (1969). Development Plan 1970-1974.

[12] Kosemani, J.M. (1995). Comparative Education: Emergent National Systems. Port Harcourt Abe, Port Harcourt.

[13] Lewis, L.J. (1962). Education and Political Independence.

[14] Najman, D. (1972). Education in Africa. What Next? Paris Deux Mille.

[15] NERC (2004). A Philosophy for Nigerian Education. Lagos NERC.

[16] Nuffield Foundation and Colonial Office (1973). African Education: A Study of Educational Policy and Practice in British Tropical African. Cambridge Conference. 
Development of Primary/Secondary Schools in Colonial Times and the Need for Sustainable Innovations, Growth and Value Creation: A Comparative Analysis

[17] Okonkwo, C. (1998). Comparative Education and Educational Decision Making. Owerri: Corporate Impressions.

[18] Sheffield, J.R. (1973). Education in Kenya: A Historical Study. New York: Teachers College Press.

[19] Stabbler, E. (1969). Education since Uhuru: The Schools in Kenya. Middleton Co. Wesley University Press.

[20] Taiwo, C.O. (1980). The Nigerian Educational System - Past Present and Future. Lagos: Thomas Nelson.

[21] Ukeje, B.O. (1989). The Role of Nigerian Education in the 1990s. A Lead Paper delivered at the $1^{\text {st }}$ Annual Conference of NAEAP held at Owerri.

[22] UNESCO/UNECA (1961). Final Report. Paris UNESCO/UNECA.

[23] Ward (1953). "The Beecher Report on African Education: Education in Kenya." Oversee Education, xiv, (4),13-19.

[24] World Bank (1974). Education. New York: World Bank.

Citation: Dr. Celestina Imade Harry. "Development of Primary/Secondary Schools in Colonial Times and the Need for Sustainable Innovations, Growth and Value Creation: A Comparative Analysis." International Journal of Humanities Social Sciences and Education (IJHSSE), vol 7, no. 3, 2020, pp. 80-89. doi: http://dx.doi.org/10.20431/2349-0381.0703010.

Copyright: (C) 2020 Authors. This is an open-access article distributed under the terms of the Creative Commons Attribution License, which permits unrestricted use, distribution, and reproduction in any medium, provided the original author and source are credited. 